\title{
PENGUJIAN TPC, KADAR AIR DAN pH PADA IKAN KAYU CAKALANG (Katsuwonus pelamis) YANG DI SIMPAN PADA SUHU RUANG
}

\author{
Patrick H Kiwak ${ }^{1}$, Albert Royke Reo ${ }^{2}$, Lita A.D.Y. Montolalu ${ }^{2}$, \\ Engel V. Pandey ${ }^{2}$, Bertie E. Kaseger ${ }^{2}$, Daisy M. Makapedua ${ }^{2}$ \\ ${ }^{1)}$ Mahasiswa pada Program Studi Teknologi Hasil Perikanan FPIK UNSRAT Manado. 95115. \\ ${ }^{2)}$ Staf pengajar pada Program Studi Teknologi Hasil Perikanan FPIK Unsrat Manado. 95115.
}

\begin{abstract}
ABSTRAK
Ikan merupakan salah satu bahan makanan yang tidak asing lagi bagi masyarakat Indonesia, bahan makanan ini memiliki kelebihan yaitu mengandung asam amino esensial yang diperlukan oleh tubuh, disamping itu nilai biologisnya mencapai $90 \%$ dengan jaringan pengikat sedikit sehingga mudah dicerna, selain itu harganya jauh lebih murah dibandingkan sumber protein lainnya.

Penelitian ini diharapkan dapat memberikan informasi tentang kajian mutu ikan kayu (Katsuobushi) secara kimia dan mikrobiologi pada penyimpanan suhu kamar. Ikan kayu dapat juga mengalami proses kerusakan namun, bila dibandingkan dengan produk lain kerusakan yang terjadi lebih lambat, Seperti diketahui bersama, bahwa kadar air produk yang rendah dapat menghambat aktivitas mikroba yang menyebabkan proses kerusakan sehingga penelitian ini untuk menganalisis kualitas mutu ikan kayu cakalang (Katsuwonus pelamis L) pada penyimpanan suhu kamar.

Hasil menunjukkan bahwa Nilai ALT (Angka Lempeng Total) ikan kayu yang disimpan selama 7 hari pada penyimpanan suhu ruang masih dalam keadaan baik dan layak digunakan sesuai dengan standar Nasional Indonesia SNI 2691.1:2009. Kadar air merupakan salah satu penentu kualitas dari produk ikan kayu dimana semakin tinggi nilai kadar air pada produk ikan kayu bakteri cemaran pada ikan kayu semakin meningkat.
\end{abstract}

Kata kunci: Katsuobushi, kualitas mutu.

Fish is one food that is not foreign to the people of Indonesia, this food has advantages that contain essential amino acids needed by the body, in addition to its biological value reaches $90 \%$ with a little binding tissue so easily digested, but it is much cheaper compared to other protein sources.

This research is expected to provide information about quality study of wood fish (Katsuobushi) in chemical and microbiology at room temperature storage. Woodfish can also be damaged but, when compared to other products, slower damage, As we all know, that low water content of the product can inhibit microbial activity causing the damage process so that this study to analyze quality of skipjack tuna (Katsuwonus pelamis L) at room temperature storage.

The results show that ALT (Total Plate Total) value of wooden fish stored for 7 days at room temperature storage is still in good condition and feasible to be used in accordance with Indonesian National Standard SNI 2691.1: 2009. Water content is one determinant of the quality of wooden fish products where the higher the value of water content in fish wood products of bacteria contaminants on wooden fish is increasing.

Keywords: Katsuobushi, quality.

\section{PENDAHULUAN}

Ikan merupakan salah satu bahan makanan yang tidak asing lagi bagi masyarakat Indonesia, bahan makanan ini memiliki kelebihan yaitu mengandung asam amino esensial yang diperlukan oleh tubuh, disamping itu nilai biologisnya mencapai $90 \%$ dengan jaringan pengikat sedikit sehingga mudah dicerna, selain itu harganya jauh lebih murah dibandingkan sumber protein lainnya (Adawyah, 2007).
Kemunduran mutu ikan disebabkan oleh aksi enzimatis dan aksi bakteri. Kedua aksi ini menguraikan komponen penyusun jaringan tubuh ikan sehingga menghasilkan perubahan fisik seperti daging ikan menjadi lunak dan perubahan kimia yang menghasilkan senyawa mudah menguap dan berbau busuk (Murniati, 2000).

Salah satu penyebab terjadinya kemunduran mutu ikan kayu yaitu kadar air. (Agus, et al. 2014) menyatakan bahwa kadar air 
merupakan parameter yang penting untuk menentukan kualitas ikan kayu yang dihasilkan. Kadar air yang terkandung di dalam ikan kayu dapat mempengaruhi daya simpan. Karena kadar air merupakan media mikroba untuk berkembang biak. Menurut Buckle et al. (1987) bahwa pengaruh kadar air sangat penting sekali dalam menentukan daya awet suatu bahan pangan karena kadar air mempengaruhi sifatsifat fisik, sifat kimia, dan kebusukan oleh mikroorganisme.

Salah satu jenis pengolahan yang dapat digunakan untuk menghambat kegiatan zat-zat mikroorganisme adalah pengasapan ikan, selain bertujuan memberikan manfaat untuk mengawetkan ikan pengolahan ikan dengan cara pengasapan juga memberi aroma yang sedap, warna kecoklatan atau kehitaman, tekstur yang bagus serta cita rasa yang khas dan lezat pada daging ikan yang diolah (Wibowo, 1996).

Ikan kayu salah satu produk olahan hasil perikanan dengan bahan baku ikan yang mengalami perlakuan pengolahan hingga terbentuk struktur daging seperti kaca (BSNI, 2009). Ikan kayu adalah salah satu jenis produk olahan ikan yang telah mengalami rangkaian proses seperti perebusan dan pengasapan bertingkat, hingga teksturnya menjadi sekeras kayu dan berwarna cokelat tua kehitaman. (Adawyah, 2007). Ikan kayu dapat juga mengalami proses kerusakan namun, bila dibandingkan dengan produk lain kerusakan yang terjadi lebih lambat, Seperti diketahui bersama, bahwa kadar air produk yang rendah dapat menghambat aktivitas mikroba yang menyebabkan proses kerusakan (Berhimpon, dkk. 2017).

\subsection{Tujuan Penelitian}

Tujuan dari penelitian ini adalah : Menganalisis kualitas mutu ikan kayu cakalang (Katsuwonus pelamis L) pada penyimpanan suhu kamar.

\subsection{Manfaat Penelitian}

Hasil Penelitian ini diharapkan dapat memberikan informasi tentang kajian mutu ikan kayu (Katsuobushi) secara kimia dan mikrobiologi pada penyimpanan suhu kamar.

\section{METODE PENELITIAN}

\section{Tempat dan Waktu Penelitian}

Penelitian ini dilaksanakan di Laboratorium Pengendalian Mutu Hasil Perikanan dan Penanganan Hasil Perikanan, Fakultas Perikanan dan Ilmu Kelautan
Universitas Sam Ratulangi Manado. Waktu yang dibutuhkan untuk penelitian adalah satu 3 minggu.

\section{Metode Penelitian}

Metode eksperimen adalah metode penelitian yang digunakan untuk mencari pengaruh perlakuan tertentu terhadap yang lain dalam kondisi yang terkendalikan (Sugiyono, 2011). Berdasarkan definisi dari beberapa ahli tersebut, dapat dipahami bahwa penelitian eksperimen adalah penelitian yang dilakukan untuk mengetahui pengaruh pemberian suatu treatment atau perlakuan terhadap subjek penelitian. Jadi penelitian eksperimen adalah kegiatan penelitian yang bertujuan untuk menilai pengaruh suatu perlakuan/tindakan/ treatment terhadap pengujian untuk menguji hipotesis tentang ada-tidaknya pengaruh tindakan itu jika dibandingkan dengan tindakan lain

\section{Bahan dan Alat}

Bahan dan alat yang digunakan dalam penelitian ini adalah sebagai berikut:

\section{Bahan}

Bahan yang digunakan Ikan kayu PT Celebes Minapratama Bitung. Bahan yang digunakan untuk pengujian kapang yaitu; media NA, Akuades, $\mathrm{NaCl}$, slikagel, dan spritus.

\section{Alat}

Alat yang digunakan dalam penelitian ini adalah kotak box, lemari penyimpanan, gunting, plastik ziplock, kertas label, cawan porselin, cawan pertri, elemeyer $1000 \mathrm{ml}$, elemeyer $250 \mathrm{ml}$, gelar ukur $1000 \mathrm{ml}$, tabung reaksi, spatula, bunsen, oven, desikator, dan inkubator.

\section{Perlakuan}

Perlakuan yang dilakukan dalam penelitian adalah sebagai berikut :

Waktu penelitian diasumsikan dilakukan pada waktu yang sama di setiap hari. Ulangan yang digunakan dalam penelitian adalah sebanyak 2 kali untuk pengujian $\mathrm{pH}$ dan kadar air, sedangkan pengujian ALT di lakukan perhitungan duplo.

Penyimpanan (A): Lama penyimpanan suhu kamar.

$\mathrm{A} 1=0$ hari (Sampel $\mathrm{A}=2$, Sampel $\mathrm{B}=2$, Sampel C=2). 
$\mathrm{A} 2=5$ hari (Sampel $\mathrm{A}=2$, Sampel $\mathrm{B}=2$, Sampel C $=2$ ).

$\mathrm{A} 3=14$ hari (Sampel $\mathrm{A}=2$, Sampel $\mathrm{B}=2$, Sampel C=2)

Jenis Sampel Ikan Kayu (B):

B1= Ikan Kayu Kualitas A

B2= Ikan Kayu Kualitas B

B3= Ikan Kayu Kualitas C

\section{Tata Laksana Penelitian} berikut:

Tata laksana penelitian adalah sebagai

1. Sampel yang digunakan dalam penelitian ini adalah ikan kayu (Katsuobushi) yang berasal dari PT Celebes Minapratama Bitung.

2. Sampel yang akan digunakan dihancurkan/diserut.

3. Kemudian sampel dikemas berdasarkan 3 kelompok dan disimpan pada suhu kamar selama 14 hari.

4. Analisa yang dilakukan meliputi Pengujian Kadar Air, pH dan pengujian ALT ( Angka Lempeng Total). Pengujian dilakukan secara bersamaan untuk ketiga parameter uji.

5. Pengujian kadar Air, dan $\mathrm{pH}$ dilakukan dengan 2 kali ulangan untuk setiap sampel, sedangkan pengujian ALT ( Angka Lempeng Total) dilakukan dengan perhitungan duplo untuk setiap sampel.

\section{Parameter Yang Diuji}

Parameter yang diuji adalah Pengujian

kadar air, pH dan Pengujian ALT (Angka Lempeng Total).

\section{Prosedur Angka Lempeng Total (ALT)} (Modifikasi SNI 01-2332.3-2006)

1. Buat tingkat pengenceran sesuai kebutuhan dengan menggunakan larutan pengenceran Natrium Klorida.

2. Pipet masing-masing $1 \mathrm{ml}$ dari pengenceran 101 - 103 ke dalam cawan petri steril secara duplo.

3. Tuangkan $20 \mathrm{ml}$ Nutrien Agar yang masih cair dengan suhu $45^{\circ} \mathrm{C} \pm 1^{\circ} \mathrm{C}$ ke dalam masing-masing cawan petri.

4. Goyangkan cawan petri dengan hati-hati (putar dan goyang ke depan, ke belakang, ke kanan dan ke kiri) sehingga contoh dan pembenihan tercampur merata dan memadat.
5. Kerjakan pemeriksaan blanko dengan mencampur air pengencer untuk setiap contoh yang diperiksa.

6. Biarkan sampai campuran dalam cawan petri memadat.

7. Masukkan semua cawan petri dengan posisi terbalik ke dalam lemari pengeram pada suhu $35^{\circ} \mathrm{C} \pm 1{ }^{\circ} \mathrm{C}$ selama 48 jam.

8. Catat pertumbuhan koloni pada setiap cawan petri yang mengandung 25 koloni250 koloni setelah 48 jam

Perhitungan :

Angka lempeng total (koloni/g) $=\mathrm{n} \times \mathrm{F}$, dengan:

$\mathrm{n}=$ rata-rata koloni dari dua cawan petri dari satu pengenceran, (koloni/g)

$\mathrm{F}=$ faktor pengenceran dari rata-rata koloni yang dipakai.

\section{Analisa Uji Kadar Air (AOAC, 1995)}

Analisis kadar air dengan menggunakan oven. Kadar air dihitung sebagai persen berat, artinya berapa gram berat contoh dengan yang selisih berat dari contoh yang belum diuapkan dengan contoh yang telah (dikeringkan). Jadi kadar air dapat diperoleh dengan menghitung kehilangan berat contoh yang dipanaskan. Urutan kerjanya sebagai berikut:

- Cawan porselen dengan penutup dibersihkan dan dikeringkan dalam oven pada suhu $105^{\circ}-110^{\circ} \mathrm{C}$ selama 1 jam. Kemudian didinginkan dalam desikator selama 30 menit dan ditimbang beratnya (A gram).

- Sampel ditimbang sebanyak 2 gram dan ditaruh dalam cawan porselen yang telah diketahui beratnya (B gram). Sampel dalam porselin ini kemudian dikeringkan dalam oven pada suhu $105^{\circ}-110^{\circ} \mathrm{C}$ sampel konstan selama 24 jam, selanjutnya didinginkan dalam desikator selama 30 menit dan ditimbang ( $\mathrm{C}$ gram).

- Penimbangan ini di ulang sampai diperoleh berat yang konstan.

Adapun persentase kadar air yang dapat dihitung sebagai berikut:

Dimana:

$$
\text { Kadar air }=\frac{(\mathrm{B}-\mathrm{C})}{(\mathrm{B}-\mathrm{A})} \times 100 \%
$$

$\mathrm{A}=$ Berat kering cawan (gr)

$\mathrm{B}=$ Berat kering cawan dan sampel awal (gr)

$\mathrm{C}=$ Berat kering cawan dan sampel setelah dikeringkan (gr). 


\section{Nilai pH}

Prosedur penentuan $\mathrm{pH}$ menurut Hari kedua (2002) adalah :

1. Ditimbang sampel yang telah dihomogenkan, dimasukkan ke dalam blender kemudian ditambahkan aquades dan diblender.

2. Dituangkan ke dalam gelas piala, kemudian ukur pHnya menggunakan $\mathrm{pH}$ meter.

3. Sebelum $\mathrm{pH}$ meter digunakan untuk mengukur $\mathrm{pH}$ sampel kepekatan ditera terlebih dulu dengan larutan buffer. Besarnya nilai $\mathrm{pH}$ sampel adalah pembacaan jarum penunjuk $\mathrm{pH}$ setelah kedudukan skalanya konstan.

\section{Analisa Data}

Data yang diperoleh kategori yaitu data kuantitatif. Data kualitatif dilakukan cukup dengan menghubungkan makna dari ke dua data uji yang dilakukan. Data kuantitatif adalah data dalam bentuk tabel-tabel, dan grafik. Data untuk uji ALT (Analisa Lempeng Total) yang diperoleh, ditentukan ditabulasi dengan mencari nilai rata-rata kemudian disajikan dalam bentuk tabel dan grafik. Data dari hasil pengujian laboratorium dipaparkan secara deskriptif.

\section{HASIL DAN PEMBAHASAN}

\section{Analisa Angka Lempeng Total (ALT)}

Pengujian Angka Lempeng Total (ALT) menunjukkan kualitas, masa simpan dan adanya kontaminasi silang pada saat proses penyimpanan suhu kamar ikan kayu berlangsung. Hasil analisa penelitian yang sudah didapatkan diolah dalam bentuk log. Hasil pengamatan ALT pada ikan kayu yang disimpan pada suhu ruang, dapat dilihat pada Gambar 1.

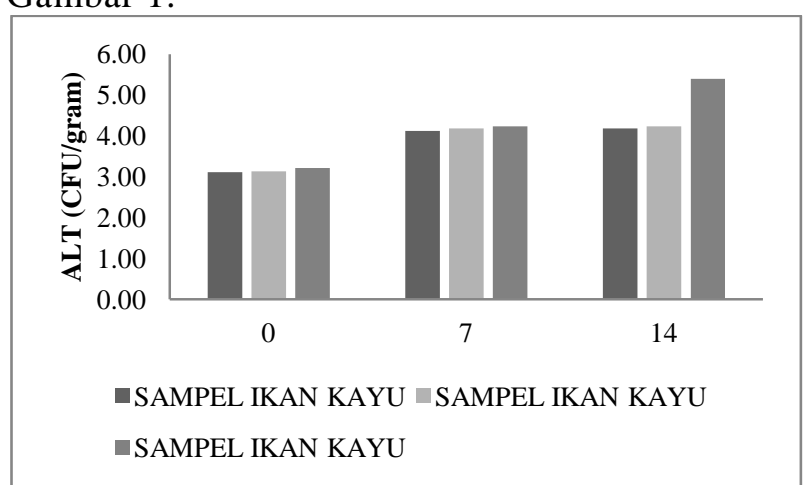

Gambar 1. Jumlah Nilai ALT Pada Ikan Kayu Yang Disimpan Pada Penyimpanan Suhu Ruang
Berdasarkan data tersebut dapat dilihat bahwa nilai ALT pada ikan kayu yang disimpan pada penyimpanan suhu ruang mengalami penurunan kualitas mutu dari semua sampel ikan kayu.

Berdasarkan data tersebut untuk sampel A pengamatan hari ke 0 pada suhu ruang memiliki nilai ALT sebesar $\log 3.11$ $\left(127.5 \times 10^{1}\right)$, sampel B pengamatan hari ke 0 pada suhu dingin memiliki nilai ALT sebesar $\log 3.13\left(135.5 \times 10^{1}\right)$ dan sampel C pengamatan hari ke 0 pada suhu dingin memiliki nilai ALT sebesar $\log 3.21\left(16.4 \times 10^{2}\right)$.

Nilai ALT pada sampel A pengamatan hari ke 7 memiliki nilai ALT sebesar log 4.12 $\left(133 \times 10^{2}\right)$, sampel $B$ pengamatan hari ke 7 memiliki nilai ALT sebesar $\log 4.18\left(151 \times 10^{2}\right)$ dan sampel $\mathrm{C}$ pengamatan hari ke 7 memiliki nilai ALT sebesar $\log 4.23\left(171 \times 10^{2}\right)$. Pada hari ke 14 nilai ALT sampel A pengamatan hari ke 14 pada suhu ruang memiliki nilai ALT sebesar $\log 4.18\left(152 \times 10^{2}\right)$, sampel B pengamatan hari ke 14 memiliki nilai ALT sebesar log 4.24 $\left(172 \times 10^{2}\right)$ dan sampel C pengamatan hari ke 14 memiliki nilai ALT sebesar log 5.40 $\left(205.5 \times 10^{3}\right)$. Penyimpanan ikan kayu pada hari ke 14 sampel A dan B masih dikatakan layak digunakan sedangkan sampel $\mathrm{C}$ sudah melebihi batas SNI ikan kayu, pada penyimpanan hari ke 14 sampel $\mathrm{C}$ ikan kayu tidak dapat digunakan karena sudah melebihi batas SNI dan sudah berkapang.

Besarnya jumlah bakteri ini disebabkan pada penyimpanan hari ke 0 , bakteri baru mulai berdaptasi dengan lingkungan yang baru, dimana bakteri mampu bertahan walaupun belum dapat berkembang biak. Pada Gambar 3 menunjukan bahwa koloni bakteri pada suhu ruang cemaran bakteri lebih cepat. Aktivitas mikroba juga dipengaruhi oleh suhu penyimpanan, dimana semakin lama penyimpanan produk maka jumlah bakteri akan meningkat.

Jumlah koloni bakteri yang tertinggi pada penyimpanan suhu kamar pada penyimpanan hari ke 14 sampel C yaitu log $5.40\left(205.5 \times 10^{3}\right)$ berdasarkan persyaratan mutu yang dikeluarkan Badan Standarisasi Nasional Indonesia (SNI) 2691.1:2009 bahwa jumlah bakteri maksimal yaitu $1.0 \times 10^{3} \mathrm{CFU} / \mathrm{gr}$, hal ini berarti jumlah bakteri pada ikan kayu dengan penyimpanan suhu ruang dapat bertahan 14 hari pada sampel A dan sampel B, sedangkan sampel C pada penyimpanan hari ke 14 ikan 
kayu sudah tidak dapat digunakan karena melebihi batas SNI dari ikan kayu.

\section{Analisa Kadar Air}

Pengujian analisa kadar air pada penelitian ini merupakan data pelengkap dimana kadar air pada ikan kayu memiliki pengaruh pertumbuhan bakteri. Hasil analisa kadar air pada ikan kayu yang disimpan pada suhu ruang dapat dilihat pada Gambar 2.

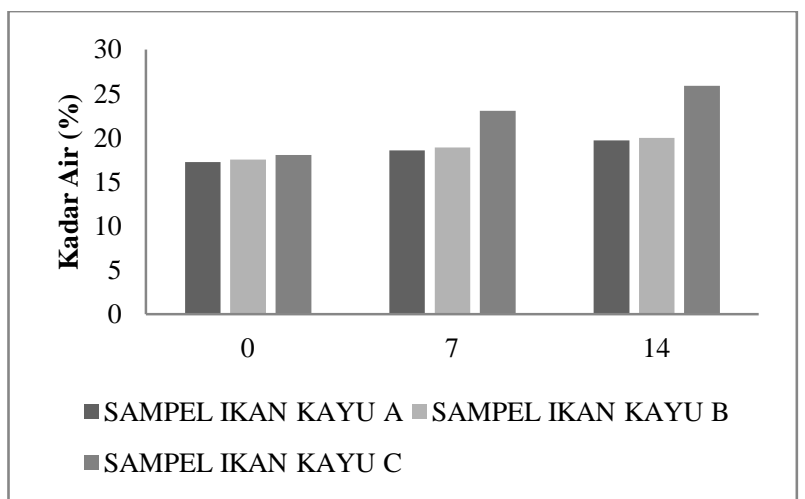

Gambar 2. Jumlah Nilai Kadar Air (\%) Pada Ikan Kayu Yang Disimpan Pada Suhu Ruang

Hasil data kadar air ikan kayu di atas mengalami peningkatan. Sampel ikan kayu pada suhu ruang semakin meningkat mulai hari ke 0 sampai hari ke 14 sehingga nilai kadar air ikan kayu pada hari ke 14 memiliki nilai kadar air pada sampel A yaitu 20\%, sampel B yaitu $20 \%$ dan sampel yaitu C 26\%, yang merupakan nilai kadar air tertinggi pada setiap sampel penyimpanan suhu ruang.

Hasil data kadar air dari ikan kayu disebabkan karena tempat penyimpanan yaitu penyimpanan suhu ruang yang menyebabkan kenaikan kadar air pada sampel A, sampel B dan sampel $\mathrm{C}$, karena pada suhu ruang ikan kayu akan meyerap kelembapan dari tempat penyimpanan. Menurut Purnomo (1996), bahwa suhu dan kelembapan tempat penyimpanan mempengaruhi kenaikan kadar air, karena produk selama penyimpanan seimbang dengan kelembapan sekitarnya, sehingga pada suhu ruang pasta akan menyerap kandungan air pada kelembapan suhu ruang dan menurut Emeliza (2017) Lamanya pengeringan membuat pertumbuhan mikroba semakin turun. Semakin sering pengeringan yang dilakukan maka tingkat pertumbuhan mikroba semakin rendah.

\section{Analisa nilai pH}

$\begin{array}{ccr}\text { Pengujian } & \mathrm{pH} \text { pada penelitian } \\ \text { merupakan data } & \text { pendukung }\end{array}$ pertumbuhan bakteri pada ikan kayu. Hasil analisa $\mathrm{pH}$ pada ikan kayu yang disimpan pada penyimpanan suhu ruang dapat dilihat pada Gambar 4.

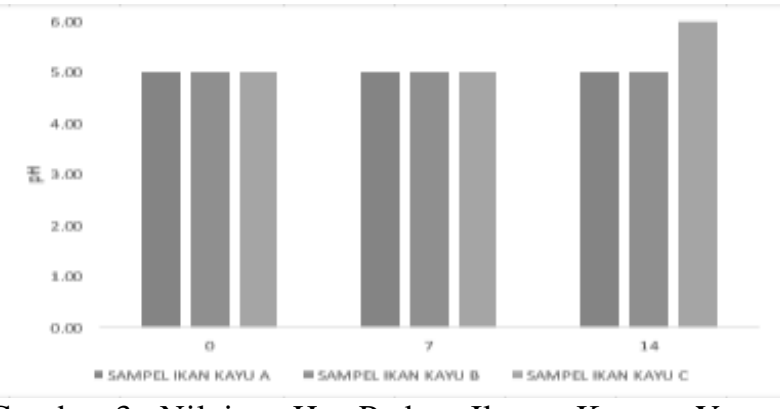

Gambar 3. Nilai pH Pada Ikan Kayu Yang Disimpan Pada Suhu Ruang

Hasil data $\mathrm{pH}$ ikan kayu, nilai pH pada penyimpanan suhu ruang, memiliki nilai $\mathrm{pH}$ namun berdasarkan data di atas $\mathrm{pH}$ tidak berbeda drastis antara sampel A, sampel B dan sampel C. Nilai pH ikan kayu pada suhu ruang pada hari ke 14 memiliki nilai 6 , yang merupakan nilai $\mathrm{pH}$ tertinggi pada penyimpanan suhu ruang. Menurut Muratore et. al. (2007), penurunan nilai $\mathrm{pH}$ disebabkan oleh metabolisme bakteri asam laktat. Pendapat tersebut didukung oleh Sthor et. al. (2001) yang menyatakan bahwa bakteri asam laktat merupakan penyebab utama penguraian kandungan gizi produk. Sedangkan menurut Berhimpon (1995), pH produk yang semakin meningkat karena selama penyimpanan terjadi penguapan senyawa-senyawa dan pengawet penting sehingga $\mathrm{pH}$ produk meningkat dan Purnomo (1997), menambahkan bahwa setiap mikroorganisme mempunyai kisaran $\mathrm{pH}$ dimana pertumbuhan masih memungkinkan dan masing-masing biasanya mempunyai $\mathrm{pH}$ optimum. Beberapa mikroorganisme dalam bahan pangan tertentu seperti $\mathrm{pH}$ pertumbuhan bakteri adalah 4,0-8,0 (Djide, 2005).

\section{KESIMPULAN DAN SARAN}

\section{Kesimpulan}

1. Nilai ALT (Angka Lempeng Total) ikan kayu yang disimpan selama 7 hari pada penyimpanan suhu ruang masih dalam keadaan baik dan layak digunakan sesuai dengan standar Nasional Indonesia SNI 2691.1:2009. Kadar air merupakan salah satu penentu kualitas dari produk ikan kayu dimana semakin tinggi nilai kadar air pada 
produk ikan kayu bakteri cemaran pada ikan kayu semakin meningkat.

2. Pengaruh tempat penyimpanan juga menentukan kualitas dari produk ikan kayu dimana ikan kayu pada suhu kamar memiliki sifat mmenarik air dari kelembapan tempat penyimpanan sehingga kadar air lebih cepat meningkat.

\section{Saran}

Penyimpanan ikan kayu sebaiknya disuhu dingin untuk mempertahankan kualitas produk secara maksimal.

\section{DAFTAR PUSTAKA}

(SNI) Standard Nasional Indonesia. 2006. Ikan Asap Bagian 1. Spesifikasi. SNI 27 25.1:2006. Badan Standardisasi Nasional. Jakarta.

Adawyah, Rabiatul. 2007. Pengolahan dan Pengawetan Ikan. Bumi Aksara. Jakarta.

Adwyah, R. 2008. Pengolahan dan Pengawetan Ikan. Penerbit. Bumi Aksara. Jakarta

Agus. T.S.W., F. Swastawati, da A.P. Anggo. 2014 Kualitas Ikan PAri (Dasyatis sp) Asap Yang Diolah Dengan Ketinggian Tungku Dan Suhu Yang Berbeda. Jurnal Pengolahan dan Bioteknologi Hasil Perikanan, vol 3. No.1 hal 147-156.

AOAC., 1995 Official Methods of Analysis of the Association of Official Analyticial. Chemists. Washington.

Badan Standarisasi Nasional Indonesia. 2009. Ikan Kayu Bagian Spesifikasi. Standar Nasional Indonesia Jakarta. SNI 02-2691.1. ICS 67. 120. 30.

Berhimpon, S., Katiandagho, Y., dan Roe, A.R. 2017. Pengaruh Konsentrasi Asap Cair dan Lama Perendaman Terhadap Mutu Organoleptik Ikan Kayu (Katsuobushi). Jurnal Media Teknologi Hasil Perikanan. Teknologi Hasil Perikanan. Universitas Sam Ratulangi, Manado. 1(5).

Buckle, K.A., R.A. Edwards., G.A. Fleet., dan M. Wooton. (1987). Food science. Universitas Indonesia. (Penerjemah: Hari Purnomo dan Adiono, Judul:Ilmu Pangan).

Charles. 2004. The End of the Line: How overfishing is changing the world and what we eat. Ebury Press, London. ISBN 0-09-189780-7.
Emeliza P, Henny D, Josefa K. Studi Keberadaan Bakteri Patogen Pada Ikan Kayu (Katsuwobushi) Yang Diproses Dengan Asap Cair. Jurnal Media Teknologi Hasil Perikanan. Universitas Sam Ratulangi, Manado.

Fardiaz. S., 1993. Analisis Mikrobiologi Pangan. PT. Raja Grasida Persada Utama. Jakarta.

Gitrix M (2007). Kekayaan Laut Indonesia. hal. 3-5. Jakarta:Sekretariat Dewan Maritim Indonesia Departemen Kelautan dan Perikanan.

Harikedua J. 2002. Metode Analisa Kimia Hasil Perikanan. Penuntun Praktikum. Fakultas Perikanan Dan Ilmu Kelautan Universitas Sam Ratulangi. Manado.

Jay. 1996. Modern Food Microbiology 4th edition. New York : D Von Nostrand Company.

Juniarto. 2003. Teknik Penanganan Ikan. Penebar Swadaya. Jakarta

Martines O, Salmero J, Guillen MD, Casa C. 2007. Textural And Physicochemical Changes In Salmon (Samo salar) Treated With Commercial Liquid Smoke Flavourings. Food Chem 100:498-503.

Murniati, A. S Dan Sunarman. 2000. Pendinginan, Pembekuan Dan Pengawetan Ikan. Penerbit Kanisius. Yogyakarta. Penerbit. Bumi Aksara. Jakarta.

Ray, 2004. Fundamental Food Mikrobiology. CRC. Presss: Boca Raton. $493 \mathrm{~h}$

Saanin, 1968. Taksonomi dan Indentifikasi Ikan 2. Pt. bina Cipta. Bogor. Jawa Barat.

Sanger, Grace. 2010. Oksidasi Lemak Ikan Tongkol (Auxfs Thazardl Asap Yang Direndam Dalam Larutan Ekstrak Daun Sirih. Pacific Journal Juli 2010 Vol 2 (5) : $870-873$.

Soepandi, T. Dan Wardah. 2013. MicrobiologiPangan . Teori dan Praktek. Andy Yogyakarta. 493 h.

Suwetja, I.K. 2011. Biokimia Hasil Perikanan, buku. Diterbitkan Oleh Media Prima Aksara. Jakarta. 204h

Tranggono dan Sutardi. 1990. Biokimia dan Teknologi Pasca Panen. Universitas gadjah mada:Yogyakarta.

Tri Margono, Detty Suryati, Sri Hartinah. 1993. Buku Panduan Teknologi Pangan. Pusat Informasi Wanita dalam Pembangunan PDII-LIPI bekerjasama dengan Swiss Development Cooperation.

Utomo, B.S.B., S. Wibowo., dan T.N. Widianto. 2012. AsapCair. Cara Membuat dan Aplikasinya pada Pengolahan Ikan. Penerbit. Bumi Aksara.

Wibowo, S. 1996. Industri Pengasapan Ikan. Penebar Swadaya. Jakarta. 